\title{
A Pharmacological Emphasized Revision on Alpha-Hederin
}

\author{
Muhammad Torequl Islam* \\ Northeast Biotechnology Network (RENORBIO), Federal University of Piauí, Brazil
}

Submission: December 03, 2016; Published: February 16, 2017

*Corresponding author: Muhammad Torequl Islam , Northeast Biotechnology Network (RENORBIO), Post-graduation Program in Biotechnology, Federal University of Piauí, Teresina (PI)-64. 049-550, Brazil, Email: mti031124@gmail.com

\begin{abstract}
Herbal medicines are a great deal of attention to investigate emphasizing on health benefits. Alpha-hederin ( $\alpha$-HN) is a plant-derived saponin having a number of important biological activities. However, the studies on this component are not enough. This revision aims at summarizing the biological roles of $\alpha$-HN including possible mechanism of actions. This study is made on the basis of evidence observed in electronic databases, Pubmed, Science Direct, Scopus, Web of Science and miscellaneous. A number of pharmacological actions of $\alpha$-HN have been investigated, including antioxidant, anti-inflammatory, antiarthritic, bronchiolytic, antifungal, and antiparasitic activities. It also has anti-histaminic and antitumor activities. In addition, desmutagenic and hepatoprotective potentials also have been shown. Physiological zinc depletion and calcium influx are the two observed toxic events in $\alpha$-HN treated rodents. However, it has synergistic effects with other chemicals, while antagonistic to a number of toxicants. The $\alpha-\mathrm{HN}$ may be an interesting phytochemical, therefore, more researches are necessary for it.

Keywords: Alpha-hederin; Antioxidant; Anti-inflammatory; Anti-cancer; Hepatoprotective

Abbreviations: • OH: Hydroxyl radical; 19-HETE: 19-hydroxyeicosatetraenoic acid; AIDS: Acquired Immunodeficiency Syndrome; ALT: Alanine Aminotransferase; CAT: Catalase; CP: Cisplatin; DPPH: 1,1-di-phenyl-2-picryl-hydrazyl; GPx: Glutathione Peroxidase; GSH: Glutathione/reduced glutathione; GST: Glutathione-S-Transferase; IFN: Interferon; IL: Interleukin; JNK: Jun amino terminal Kinase; LDH: Lactase Dehydroginase; LP: Lipid Peroxidation; MT: Metallothionein; NF-кB: Nuclear Factor Kappa B; NO: Nitric Oxide; $\mathrm{O}_{2} \bullet-$ : Superoxide Anion; OVA: Ovalalbumin; PAHs: Polycyclic Aromatic Hydrocarbons; RBC: Red Blood Cells/Corpuscles; ROS: Reactive Oxygen Species; SAPK: Stress-Activated Protein Kinases; TCDD: 2,3,7,8-tetrachlorodibenzo-p-dioxin; TQ: Thymoquinone; WBC: White Blood Cells/Corpuscles; $\alpha$-HN: Alpha-Hederin; $\beta$-HN: Beta-Hederin; $\delta$-HN: Delta-Hederin
\end{abstract}

\section{Introduction}

Hederagenin is the aglycone part of a numerous saponins found in Hedera helix (common ivy). It was discovered by L. Posselt in 1849 and named as the hederic acid [1]. The most prevalent of these being hederacoside $\mathrm{C}$ and alpha-hederin $(\alpha-H N)$ (Figure 1). The $\alpha-H N$ also to be found in Chenopodium quinoa, Kalopanax pictus and Nigella sativa plants. The $\alpha-\mathrm{HN}$, a monodesmosidic triterpenoid saponin having important biological activities [2,3]. It is white to off-white crystalline powder and also known as $(3 \beta, 4 \alpha)-3-[[2-0-(6-$ Deoxy- $\alpha-\mathrm{L}-$ mannopyranosyl)- $\alpha$-L-arabinopyranosyl]oxy]-23-hydroxyolean12-en-28-oic acid. Its chemical formula is $\mathrm{C}_{41} \mathrm{H}_{66} \mathrm{O}_{12}$; molecular weight: 750.96 and melting point: $128-268^{\circ} \mathrm{C}$. The $\alpha-\mathrm{HN}$ is stable under normal condition and incompatible with acids, reducing agents and oxidizing agents; soluble in ethanol, di-methyl sulfoxide and di-methylformamide.

The $\alpha$-HN and its few analogues have been proven to have antioxidant, anti-inflammatory, cytotoxic and antitumor activities. The aim of this revision is forwarded to sketch the findings on $\alpha-\mathrm{HN}$ in association with the possible mechanisms of action emphasizing on observed pharmacological activities. For this purpose, I have selected published articles in different databases such as ScienceDirect, PubMed, Web of Science, Scopus and miscellaneous. Then the articles were sorted according to the observed biological properties. Articles containing the same information with same compounds were replaced by the most recent one. However, other hederins are also considered in this study.

\section{Search Strategy}

I searched in the above mentioned databases for basic and pre-/ clinical articles published up to March 2016. The relevant terms "hederagenin", "alpha-hederin" were paired with classical activities"antioxidant", "anti-inflammatory", "antiarthritic", "anti-spasmodic", "anti-microbial”, "anti-bacterial”, "anti-fungal”, "anti-viral”, "antiparasitic", “anti-leishmaniasis", "hepatoprotective”, "anti-cancer”, 
"cytotoxicity", "genotoxicity" and "mutagenicity". No language restrictions were imposed. The search yielded 149 references. Then the list was reduced to 98 references, which were further scrutinized by reading each abstract and after discarding 60, attention was given on 38 papers.

\section{Findings on Alpha-hederin ( $\alpha-\mathrm{HN})$}

\section{In oxidation}

Mice when treated subcutaneously (s.c.) with 10 and $30 \mathrm{mM} / \mathrm{kg}$ of $\alpha-\mathrm{HN}$ for 3 days exhibited an increase in hepatic reduced glutathione (GSH), glutathione peroxidase (GPx) and glutathione-S-transferase (GST) levels. Although, there was a decreased in catalase (CAT) level observed with the highest treated dose $(30 \mathrm{mM} / \mathrm{kg})$ but increased metallothionein (MT) with an elevation of hepatic $\mathrm{Zn}$ and $\mathrm{Cu}$ concentrations along with ascorbic acid concentration were demonstrated [4]. Otherwise, $\alpha$-HN is evident to exhibit 1,1-di-phenyl-2-picryl-hydrazyl $(\mathrm{DPPH})$, superoxide anion $\left(\mathrm{O}_{2} \bullet-\right)$ and hydroxyl $(\bullet \mathrm{OH})$ radicals scavenging along with a significant lipid peroxidation (LP) potential [5].

Glutathione (GSH) is an important antioxidant in living systems, preventing damage to important cellular components caused by reactive oxygen species (ROS) such as free radicals, peroxides, lipid peroxides and heavy metals [6]. Otherwise, MTs, a cysteine-rich family with low molecular weight (MW: 500 to $14000 \mathrm{Da}$ ) proteins are localized to the membrane of the Golgi apparatus capable to bind with physiological and xenobiotic heavy metals (e.g.-Zn, $\mathrm{Cu}, \mathrm{Se}, \mathrm{Cd}, \mathrm{Hg}$ ) through its thiol group in cysteine residues. MTs are evident to provide protection against metal toxicity, mainly through the regulation of $\mathrm{Zn}$ and $\mathrm{Cu}$ and provide protection against oxidative stress [7]. Thus, along with the anti-radical power an increase in GSH and MT levels with the $\alpha$-HN treatment confirming its potential antioxidant capacity.

\section{In inflammation and arthritis}

Ovalalbumin (OVA)-sensitized male adult guinea pigs $(\mathrm{n}=8)$ treated with $0.3-3.0 \mathrm{mg} / \mathrm{kg} \quad \alpha-\mathrm{HN}$ intraperitoneally (i.p.) significantly decreased the pro-inflammatory mediators interleukin (IL) -2,-4 and -17 with an increased level in interferongamma (IFN- $\gamma$ ) [8]. It also caused a decrease in histamine levels and white blood cells (WBCs), basophil and eosinophil counts with an increased in the neutrophil, lymphocyte and monocyte counts [9]. However, rats $(\mathrm{n}=6)$ treated with $0.02 \mathrm{mg} / \mathrm{kg}$ (i.p.) caused a reduction in IL-2 and -17 mRNA levels with an increased in anti-arthritic and bronchiolytic effects through miRNA-133a gene expression [10]. Otherwise, $\alpha-\mathrm{HN}$ also exhibited an antiinflammatory activity in carrageenan and isoprenaline-induced animal models $[2,11]$. In the latter case it was supposed to act through inhibiting heterologous desensitization induced by high concentrations of muscarinic ligands like methacholine [11]. In addition, $\alpha-\mathrm{HN}$ at 0.02 and $20 \mathrm{mg} / \mathrm{kg}$ (i.p.) in carrageenaninduced acute edema rats imparted an anti-inflammatory effect by blocking bradykinin and inflammation mediators [12].
To be mentioned that IL-2 and -4 are responsible for the proliferation of responsive $\mathrm{T}$ and $\mathrm{B}$ cells, respectively. In addition, IL-2 also acts on some B cells and causes stimulation to the growth factor and antibody production [13]. Otherwise, IL-17 is a potent pro-inflammatory cytokine produced by activated memory T cells [14]. However, the majority of ILs is synthesized by helper CD4 T lymphocytes, as well as through monocytes, macrophages, and endothelial cells. The IFN- $\gamma$ (type II interferon) induces innate and adaptive immunity against viral, some bacterial and protozoal infections. It is an important activator of macrophages [15]. Thus, the increased levels of IL$2,-4,-17$, IFN- $\gamma$ and lymphocytes with the $\alpha$-HN treatment may be due to its potential anti-inflammatory activity.

Otherwise, histamine, the organic nitrogenous compound produced by basophils and by mast cells found in nearby connective tissues, as a part of an immune response increases the permeability of the capillaries to WBC and some proteins, to allow them to engage pathogens in the infected tissues [16]. It involves in the inflammatory responses and has a central role as a mediator of pruritus [17]. In addition, neutrophil forms an essential part of the innate immune system [18]. However, along with innate immunity, monocytes take a part in the adaptive immunity. Arthritis, on the other hand, is a form of joint disorder involving inflammation in one or more joints, where pain comes from the inflammation. Otherwise, bronchitis is the inflammation of the bronchi in the lungs, including the symptoms of mucus, wheezing, shortness of breath, and chest discomfort. In addition, methacholine, a synthetic choline ester that acts as a nonselective muscarinic receptor agonist in the parasympathetic nervous system, which is primarily used to diagnose bronchial hyperreactivity and one of the hallmarks of asthma also occurs in chronic obstructive pulmonary disease [19]. The overall findings suggesting to consider the $\alpha-\mathrm{HN}$ as a hopeful anti-inflammatory, anti-arthritic and bronchiolytic agent.

\section{Against fungi and parasites}

$\alpha-\mathrm{HN}$ was found to act against Candida albicans with $6.25,12.5$ and $25 \mu \mathrm{g} / \mathrm{mL}$. Along with the modification of cellular contents and alterations in the cell envelope, it caused degradation and death of C. albicans with a half minimal inhibitory concentration (IC ${ }_{50}$ ) of $25 \mu \mathrm{g} / \mathrm{mL}$ [20]. The $\alpha-\mathrm{HN}$ also exhibited anti-Leishmania promastigotes activity with or without treatment with $\beta$-hederin $(\beta-\mathrm{HN})$ (Figure 1). A cytotoxic activity against human monocytes (THP1 cells) was also observed alongside this treatment. However, in both cases $\alpha-\mathrm{HN}\left(\mathrm{IC}_{50}: 0.25\right.$ to $13.6 \mu \mathrm{M}$ ) was founded more potent than $\beta$-HN ( IC $_{50}: 2.25$ to $3.17 \mu \mathrm{M}$ ), as it leaded a strong anti-proliferative activity on all stages of development of the parasite with an alteration in the membrane integrity and potential $[21,22]$.

C. albicans, a diploid fungus presents oral and genital infections and candidal onychomycosis in human. However systemic fungal infections may lead to morbidity and mortality in 
immunocompromised patients (e.g. -AIDS, cancer chemotherapy, organ or bone marrow transplantation) [23,24]. Otherwise, Leishmaniasis, in human is caused by more than 20 species of
Leishmania. It presents ulcer of the skin, mouth, and nose with fever, low red blood cells (RBCs), and enlarged spleen and liver $[25,26]$.

\section{In cancer}

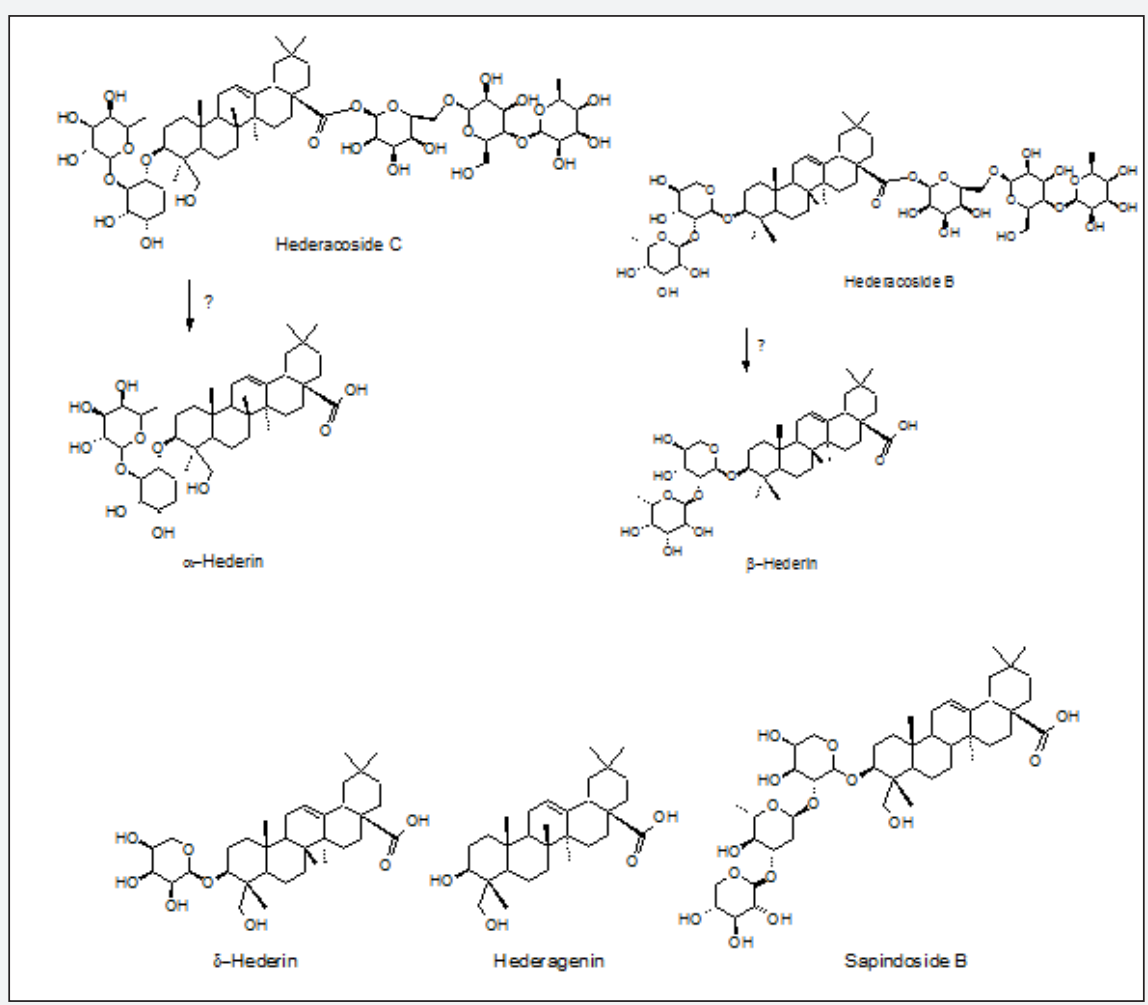

Figure 1: Chemical structures of hederacosides and respective derived hederins.

Both $\alpha$-HN and delta-hederin $(\delta$-HN) (Figure 1$)$ are evident to cause membrane pore formation. Their introduction inside the cell is assumed via sterol-dependent pathway [27,28]. An earlier report also suggesting $\alpha-\mathrm{HN}$ to cause vacuolization of the cytoplasm and alteration of the cell membrane leading to cell death in melanoma and non-cancer mouse 3T3 fibroblasts cells [29]. Otherwise, an uprregulation of nuclear factor kappa B (NF$\kappa \mathrm{B})$ and Caspase-3 dependent pathways leading to produce nitric oxide (NO) and ROS are evident to cause oxidative damage of cells in BALB/C mice and murine leukemia P388 cells, respectively [30,31]. In MCF-7 and MDA-MB-231 human breast cancer cells, $\alpha-\mathrm{HN}(0.008-10 \mu \mathrm{g} / \mathrm{mL})$ induced apoptosis and caused a depolarization of mitochondrial membrane potential leading to release of Apaf-1 (apoptosome) and cytochrome c and activation of Caspase-3 and -9 [3]. The $\alpha-\mathrm{HN}(8-20 \mu \mathrm{M})$ is also evident to induce cell necrosis and apoptosis in HEp-2 (larynx carcinoma) cells [32]. However, $\alpha-H N(0.1-5 \mu \mathrm{M})$ with pentoxifylline exhibited cytotoxicity by downregulation of the mRNA levels of TNF- $\alpha$ and IL-6 in murine hepatoma (Hepa-1c1c7) and murine macrophage (RAW 264.7) cell lines [33].

On the other hand, $\beta$-HN, other than $\alpha-\mathrm{HN}$ exhibited significant cytotoxic activity in human HeLa, MCF-7, HL-60, HT1080 and HepG2 cell lines, where the IC50 values were found in between 4.74 and $>100 \mu \mathrm{M}$ [34]. However, $\alpha-\mathrm{HN}$ also found to act against a number of human cancer cell lines including colon cancer (HT-29) with 5-fluorouracil (5-FU) and 3-0-alpha-L: -rhamnopyranosyl-(1-->2)-alpha-L: -arabinopyranoside [35,36]. In both cases, the activity was considered synergistic as the cotreated groups caused significant death of the tested cell lines than the individually treated groups. In addition, $\alpha-\mathrm{HN}$ also evident to produce an antitumor activity against murine leukemia (P388) and Lewis lung carcinoma (LL/2), human kidney (HEK293), smooth muscle (HASM) and tranfection of HEK293 cell lines $[37,38]$. Otherwise, $\alpha-\mathrm{HN}$ and/or its $\alpha-\mathrm{HN}$ chitosan nanoparticles $(\alpha$-HN-CS-CD147-NPs) $(148.23 \pm 1.75 \mathrm{~nm})$ at a dose of $50 \mu \mathrm{g} / \mathrm{mL}$ exhibited strong antitumor activity on HepG2 and SMMC-7721 cell lines. However, the activity of $\alpha$-HN-CS-CD147-NPs was considered more prominent than $\alpha-\mathrm{HN}$ [39].

To be mentioned that the $\alpha-\mathrm{HN}(0.13-13 \mathrm{nM} / \mathrm{mL})$ was found non-mutagenic in doxorubicin (DOX)-induced toxicity in human lymphocytes [40].

The NF- $\kappa B$ can be stimulated by stress, cytokines, free radicals and so on [41]. The activated NF- $\kappa B$ is translocated into the nucleus after binding to specific sequences of DNA (response elements) and recruits other proteins such as co-activators 
and RNA polymerase, leading to transcribe downstream DNA into mRNA, which results in a change of cell function [42]. Thus an incorrect regulation of NF- $\kappa B$ may be linked to cancer, inflammatory and autoimmune diseases, immune-suppression and other diseases [43]. The source of ROS is a vast. ROS, the chemically reactive molecules containing oxygen like peroxides, $\mathrm{O}_{2} \bullet$-, $\bullet \mathrm{OH}$, and singlet oxygen have an important role in cell signaling and homeostasis [44]. However, excess production of ROS is involved in cellular detrimental effects, including cancer and cell death. Otherwise, NO is also an important cellular signaling molecule and a powerful vasodilator with a short half-life [45]. NO can be produced by NOS dependent and independent pathways. Along with a number of beneficial effects, excess amount of NO can contribute to reperfusion injury following a period of ischemia and by reacting with superoxide $\left(\mathrm{O}_{2} \bullet-\right)$, it produces the damaging oxidant peroxynitrite. The $\alpha-\mathrm{HN}$ in BALB/C mice and murine leukemia P388 cells $[30,31]$ produced cytotoxicity via over production of ROS and NO may be the detrimental effects of it. However, in MCF-7 and MDAMB-231 human breast cancer cells $\alpha-\mathrm{HN}$ induced apoptosis and depolarization of mitochondrial membrane potential [3] and in HEp-2 (larynx carcinoma) cells necrosis and apoptosis [32] may be linked to the $\alpha$-HN-mediated pro-oxidant activity as the upregulation of NF- $\kappa \mathrm{B}$ may link to oxidative stress. In addition, Caspase-9, the initiator Caspase encoded by the CASP9 gene is linked to the mitochondrial death pathway. It is activated during programmed cell death (apoptosis). After an induction of stress signaling pathways Jun amino terminal kinase (JNK)/ Stress-activated protein kinases (SAPK) causes the release of cytochrome $\mathrm{c}$ from the mitochondria and activation of Apaf-1. On the other hand, Caspase-3 (encoded by CASP3 gene) is a Caspase protein that interacts with Caspase- 8 and Caspase-9, sequential activation of which results in cell apoptosis. Thus the activation of Caspase -3 and -9 and release of Apaf- 1 and cytochrome $c$ is linked together during programmed cell death. Otherwise, the IL-6 (encoded by IL6 gene) may act as both a pro-inflammatory cytokine and an anti-inflammatory myokine [46]. IL-6 is secreted by $\mathrm{T}$ cells and macrophages to stimulate immune response, e.g. during infection and after trauma, especially burns or other tissue damage leading to inflammation. Otherwise, during signaling pathways of TNF- $\alpha, \mathrm{NF}-\kappa \mathrm{B}$, translocates to the nucleus and mediates the transcription of a vast array of proteins involving in cell survival and proliferation, inflammatory response, and antiapoptotic factors. Thus, the downregulation of IL- 6 and TNF- $\alpha$ in the murine hepatoma (Hepa-1c1c7) and murine macrophage (RAW 264.7) cell lines [33] is helpful for cell death.

\section{On hepatic system}

Liu et al. [47] suggested that $\alpha-\mathrm{HN}$ is hepatoprotective through the suppression of $\mathrm{P} 450$ system in acetaminophen-, bromobenzene-, carbon tetrachloride $\left(\mathrm{CCl}_{4}\right)^{-}$, furosemide-, thioacetamide-, chloroform $\left(\mathrm{CHCl}_{3}\right)$ and dimethylnitrosamineinduced liver injury in mice. Shi \& Liu [48] also found a similar activity when mice were treated with $\alpha-\mathrm{HN}$ and/or sapindoside
B (Figure 1) at 20mg/kg (s.c.) for 3 days. Jeong [49] suggested $\alpha$-HN specifically decrease the activities of cytochrome P (CYP)4501A1, -4501A2, and -4502E1. There was also a demonstration about the downregulation of the activities of microsomal ethoxyresorufin 0-deethylase, methoxyresorufin 0-demethylase and aniline hydroxylase. However, the animals of the co-treatment group were significantly protected than the groups treated with $\alpha-\mathrm{HN}$ and sapindoside B alone. Before this, Liu et al. [50] found an increased levels of hepatic MT-I and -II in cadmium (Cd)-induced liver injured mice with the s.c. treatment of $\alpha-\mathrm{HN}$ at $10-300 \mathrm{mM} /$ $\mathrm{kg}$. Otherwise, prevention in the augmented levels of serum alanine aminotransferase (ALT), lactase dehydroginase (LDH) and LP activities was also noted in CCl4-induced hepatotoxic mice [51]. In addition, $\alpha-H N(0.1-20 \mu \mathrm{M})$ is also evident to cause suppression of 2,3,7,8-tetrachlorodibenzo-p-dioxin (TCDD)induced Cyp1a-1 gene expression with an antagonistic effect of the DNA binding potential of a nuclear Ah receptor in mouse hepatoma (Hepa-1c1c7) cell line [52].

CYP4501A1 is a substrate-inducible microsomal enzyme that oxygenates polycyclic aromatic hydrocarbons, especially those are carcinogenic to convert them as water-soluble derivatives [53]. Diseases associated with CYP4501A1 include ehrlich tumor carcinoma and pyridoxine deficiency. Otherwise, CYP4501A2 is a monooxygenase protein, catalyzes many reactions involved in drug metabolism and synthesis of cholesterol, steroids and other lipids. However, it is able to metabolize some polycyclic aromatic hydrocarbons (PAHs) to carcinogenic intermediates. Other xenobiotic substrates for this enzyme include caffeine, aflatoxin B1, and acetaminophen. It metabolizes arachidonic acid to 19-hydroxyeicosatetraenoic acid (19-HETE), which constricts arterioles, elevates blood pressure, promotes inflammation responses, and stimulates the growth of various types of tumor cells [54]. CYP4502E1 gene, especially encodes a member of the cytochrome P450 super-family of enzymes. Ethoxyresorufin [55], methoxyresorufin and aniline appear to be metabolized by a group of CYP450 isoenzymes. Thus, the decreased levels of CYP450 enzymes-mediated low microsomal ethoxyresorufin O-deethylase, methoxyresorufin 0 -demethylase and aniline hydroxylase levels [49] may be linked in. MT protein acts as a primary metal storage, transport and detoxification [56]. In addition, ALT, LDH and LP are the biomarkers considered during liver injury. Thus, the modulatory effects on the overall genes and other biomarkers may be associated in hepatoprotective potential of $\alpha-\mathrm{HN}$.

\section{Miscellaneous}

Rats when treated with $\alpha$-HN exhibited Zn depilation with a decreased fetal weight and increased the incidence of abnormal fetuses at high dose (300m M/kg) [57]. Duffy et al. [58] suggested a secondary Zn deficiency in rats treated with $\alpha$-HN at 20 or $30 \mathrm{mM} / \mathrm{kg}$ for 10 days. Male Wistar rat isolated stomach corpus and fundus strips treated with $\alpha-\mathrm{HN}(100 \mu \mathrm{M})$ exhibited $\mathrm{Ca}^{2+}$ influx via voltage-dependent calcium channels of L-type [59]. 


\section{Journal of Complementary Medicine \& Alternative Healthcare}

Zinc $\left(\mathrm{Zn}^{2+}\right)$ is found in nearly 100-300 specific enzymes, serving as a structural ion in transcription factors and is stored and transferred in MPs [60]. $\mathrm{Zn}$ is a key factor in prostate gland function and reproductive organ growth [61], metabolism of RNA and DNA, signal transduction as well as gene expression. It also regulates apoptosis and modulates brain excitability [62]. However, the augmented level of $\mathrm{Zn}$ can be toxic to the nervous system [63]. On the other hand, intracellular calcium Table 1: Findings on $\alpha$-hederin (along with other chemical moieties) in a brief.
$\left(\mathrm{Ca}^{2+}\right)$ may cause oxidative stress and apoptosis to the cells, and thus producing several diseases, especially cardiac myocyte experiences with $\mathrm{Ca}^{2+}$ influx. It also impairs kidney function and decreases absorption of other minerals $[64,65]$. Thus, $\mathrm{Zn}^{2+}$ depilation and $\mathrm{Ca}^{2+}$ influx phenomena may be a major concern to the toxicological studies of $\alpha-\mathrm{HN}$ [66]. The overall findings in a brief are shown in Table 1.

\begin{tabular}{|c|c|c|c|}
\hline $\begin{array}{l}\text { Dose(drug)/Route of } \\
\text { Administration }\end{array}$ & Test System & Activity & References \\
\hline 10 and $30 \mathrm{mM} / \mathrm{kg}$ (s.c.) for 3 days & In mice & $\begin{array}{l}\text { Increased liver GSH, GPx and GST levels. } \\
\text { Decreased CAT with } 30 \mathrm{mM} / \mathrm{kg} \text { but increased } \\
\text { MP with an elevation of hepatic Zn and } \mathrm{Cu} \\
\text { concentrations along with ascorbic acid } \\
\text { concentration }\end{array}$ & Liu \& Liu [4] \\
\hline- & $\begin{array}{l}\text { Antioxidant tests: DPPH, } \mathrm{O}_{2} \bullet-, \bullet \\
\text { OH free radical scavenging, total } \\
\text { antioxidant activity, reducing } \\
\text { power and metal chelating } \\
\text { activities }\end{array}$ & $\begin{array}{l}\text { Anti-radical, at concentration of } 75 \mathrm{pg} / \mathrm{mL} \\
\text { showed } 94 \% \text { inhibition on } \mathrm{LP}\end{array}$ & Gülçin et al. [5] \\
\hline $0.3-3.0 \mathrm{mg} / \mathrm{kg}$ (i.p.) & $\begin{array}{l}\text { In OVA- sensitized male adult } \\
\text { guinea pigs }(n=8)\end{array}$ & $\begin{array}{l}\text { Decreased levels of IL-2, IL-4 and IL-17 with } \\
\text { an increased level of IFN- } \gamma\end{array}$ & Keyhanmanesh et al. [8] \\
\hline $0.3-3.0 \mathrm{mg} / \mathrm{kg}$ (i.p.) & $\begin{array}{l}\text { In OVA- sensitized male adult } \\
\text { guinea pigs }(\mathrm{n}=8)\end{array}$ & $\begin{array}{c}\text { Decreased histamine levels and WBC, } \\
\text { basophil and eosinophil counts; increased } \\
\text { in neutrophil, lymphocyte and monocyte } \\
\text { counts }\end{array}$ & Saadat et al. [9] \\
\hline $0.02 \mathrm{mg} / \mathrm{kg}$ (i.p.) & OVA-sensitized male rats $(n=6)$ & $\begin{array}{l}\text { Decreased IL-2 and IL-17 mRNA levels } \\
\text { with an increased in miRNA-133 a gene } \\
\text { expression }\end{array}$ & Ebrahimi et al. [10] \\
\hline $\begin{array}{l}\text { With its methyl ester at 60mg/ } \\
\text { kg (p.o.) }\end{array}$ & $\begin{array}{l}\text { In carrageenan-induced edema } \\
\text { rats and mice }\end{array}$ & Produced anti-arthritic activity & Li et al. [2] \\
\hline 0.02 and $20 \mathrm{mg} / \mathrm{kg}$ (i.p.) & $\begin{array}{l}\text { In carrageenan-induced acute paw } \\
\text { edema in rats }(n=7)\end{array}$ & $\begin{array}{l}\text { Imparted anti-inflammatory effects by } \\
\text { blocking bradykinin or other inflammation } \\
\text { mediators }\end{array}$ & Gepdiremen et al. [12] \\
\hline 1 and $100 \mu \mathrm{M}$ & $\begin{array}{l}\text { On isoprenaline-induced } \\
\text { relaxation in bovine tracheal } \\
\text { smooth muscle strips. }\end{array}$ & $\begin{array}{l}\text { Bronchiolytic effect by inhibiting } \\
\text { heterologous desensitization induced by } \\
\text { high concentrations of muscarinic ligands } \\
\text { like methacholine }\end{array}$ & Wolf et al. [11] \\
\hline $100 \mu \mathrm{M}$ & $\begin{array}{c}\text { On male wistar rat isolated } \\
\text { stomach corpus and fundus strips }\end{array}$ & $\begin{array}{l}\text { Cholinergic pathways do not participate in } \\
\alpha \text {-HN-evoked contraction }\end{array}$ & Mendel et al. [58] \\
\hline $6.25,12.5$ and $25 \mu \mathrm{g} / \mathrm{mL}$ & On Candida albicans & $\begin{array}{l}\text { Induced modification of cellular contents } \\
\text { and alterations of cell envelope with } \\
\text { degradation and death with an IC50 of } \\
25 \mu \mathrm{g} / \mathrm{mL}\end{array}$ & $\begin{array}{l}\text { Moulin-Traffort et al. } \\
\qquad[20]\end{array}$ \\
\hline With $\beta$-HN & $\begin{array}{l}\text { In Leishmania promastigotes and } \\
\text { human monocytes (THP1 cells). }\end{array}$ & $\begin{array}{l}\text { Exhibited strong anti-proliferative activity } \\
\text { on all stages of development of the parasite } \\
\text { by altering membrane integrity and } \\
\text { potential. } \alpha \text {-hederin produced IC50 }=0.25 \text { to } \\
13.6 \mu \mathrm{M} \text {, while } \beta \text {-hederin by } 2.25 \text { to } 3.17 \mu \mathrm{M}\end{array}$ & Delmas et al. [21] \\
\hline With $\beta$-HN & $\begin{array}{l}\text { On Leishmania Mexicana in their } \\
\text { promastigote and amastigote } \\
\text { forms }\end{array}$ & $\begin{array}{l}\text { Exhibited strong anti-proliferative activity } \\
\text { on all stages of development of the parasite }\end{array}$ & Ridoux et al. [22] \\
\hline- & $\begin{array}{l}\text { On mouse B16 melanoma and } \\
\text { non-cancer mouse 3T3 fibroblasts } \\
\text { cells }\end{array}$ & $\begin{array}{l}\text { Induced vacuolization of the cytoplasm and } \\
\text { membrane alterations leading to cell death }\end{array}$ & Danloy et al. [29] \\
\hline 0.5 and $1 \mu \mathrm{M}$ & In BALB/C mice & $\begin{array}{c}\text { Stimulated NO release via upregulation } \\
\text { of iNOS expression through NF- } \mathrm{KB} \\
\text { transactivation. }\end{array}$ & Jeong \& Choi [30] \\
\hline
\end{tabular}




\section{Journal of Complementary Medicine \& Alternative Healthcare}

\begin{tabular}{|c|c|c|c|}
\hline- & In murine leukemia P388 cells & $\begin{array}{l}\text { Caused disruption of mitochondrial } \\
\text { membrane potential and subsequently } \\
\text { increased the production of ROS with } \\
\text { Caspase- } 3 \text { activation }\end{array}$ & Swamy \& Huat [31] \\
\hline $0.008-10 \mu \mathrm{g} / \mathrm{mL}$ & $\begin{array}{l}\text { In MCF-7 and MDA-MB- } 231 \\
\text { human breast cancer cells }\end{array}$ & $\begin{array}{l}\text { Induced apoptosis and caused a } \\
\text { depolarization of mitochondrial membrane } \\
\text { potential leading to release of Apaf- } 1 \text { and } \\
\text { cytochrome c and activation of Caspase- } 3 \\
\text { and }-9\end{array}$ & Cheng et al. [3] \\
\hline With $\mathrm{CP}$ and $\mathrm{TQ}$ at $6-14 \mu \mathrm{M}$ & $\begin{array}{l}\text { On human A549 (lung carcinoma), } \\
\text { Hep-2 (larynx epidermoid } \\
\text { carcinoma), HT-29 (colon } \\
\text { adenocarcinoma) and MIA PaCa-2 } \\
\text { (pancreas carcinoma) cell lines }\end{array}$ & $\begin{array}{l}\text { Enhanced neither cytotoxicity nor apoptosis } \\
\text { of these cancer cells (IC50 values ranging } \\
\text { from } 5.4-27.1 \mu \mathrm{M})\end{array}$ & Rooney \& Ryan [32] \\
\hline $8-20 \mu \mathrm{M}$ & In HEp-2 (larynx carcinoma) cells & Produced necrosis and apoptosis activity & Rooney \& Ryan [32] \\
\hline With pentoxifylline at $0.1-5 \mu \mathrm{M}$ & $\begin{array}{l}\text { In murine hepatoma (Hepa-1c1c7) } \\
\text { and murine macrophage (RAW } \\
\text { 264.7) cell lines }\end{array}$ & $\begin{array}{l}\text { Decreased production of production and } \\
\text { mRNA levels of TNF- } \alpha \text { and IL-6 }\end{array}$ & Kim et al. [33] \\
\hline$\beta-\mathrm{HN}$ & $\begin{array}{l}\text { On HeLa, MCF-7, HL-60, HT1080 } \\
\text { and HepG2 cell lines }\end{array}$ & $\begin{array}{l}\text { Cytotoxic activity with the IC } 50 \text { values } \\
\text { between } 4.74 \text { to }>100 \mu \mathrm{M}\end{array}$ & Liu et al. [34] \\
\hline With $\delta$-HN & - & $\begin{array}{l}\text { Pore formation and sterol-dependent } \\
\text { introduction into the cells }\end{array}$ & Lorent et al. [27] \\
\hline- & - & $\begin{array}{l}\text { Pore formation and sterol-dependent } \\
\text { introduction into the cells. }\end{array}$ & Lorent et al. [28] \\
\hline $\begin{array}{l}\text { With 3-0-alpha-L: } \\
\text {-rhamnopyranosyl-(1-->2)- } \\
\text { alpha-L: -arabinopyranoside }\end{array}$ & $\begin{array}{l}\text { In human cancer cell lines (A-549, } \\
\text { SK-OV-3, and SK-MEL-2) }\end{array}$ & Significant anticancer activity & Bang et al. [35] \\
\hline With $5-\mathrm{FU}$ at $0.001-100 \mu \mathrm{M}$ & $\begin{array}{l}\text { On colon adenocarcinoma (HT-29) } \\
\text { cell line }\end{array}$ & Synergistic anticancer effects & Bun et al. [36] \\
\hline $\begin{array}{l}5 \text { and } 10 \mathrm{mg} / \mathrm{kg} \mathrm{mg} / \mathrm{kg} \text { (p.o.) for } \\
7 \text { days }\end{array}$ & $\begin{array}{l}\text { In murine leukemia (P388) and } \\
\text { Lewis lung carcinoma (LL/2) cell } \\
\text { lines in C57BL/6 } \mathrm{DBA} / 2 \text { mice }\end{array}$ & Antitumor activity & Kumara \& Huat [37] \\
\hline $1 \mu \mathrm{M}$ & $\begin{array}{l}\text { On human kidney cells (HEK293), } \\
\text { smooth muscle cells (HASM) and } \\
\text { tranfection of HEK293 Cells }\end{array}$ & Antitumor activity against the cell lines & Sieben et al. [38] \\
\hline $\begin{array}{c}\text { With } \alpha \text {-HN chitosan } \\
\text { nanoparticles }(148.23 \pm 1.75 \mathrm{~nm}) \\
50 \mu \mathrm{g} / \mathrm{mL}\end{array}$ & $\begin{array}{l}\text { In HepG2 and SMMC-7721 cell } \\
\text { lines }\end{array}$ & $\begin{array}{l}\text { Strong antitumor activity of } \alpha \text {-HN-CS- } \\
\text { CD147-NPs }\end{array}$ & Zhu et al. [39] \\
\hline $0.13-13 \mathrm{nM} / \mathrm{mL}$ & $\begin{array}{l}\text { In DOX-induced toxicity in human } \\
\text { lymphocytes }\end{array}$ & Produced a desmutagenic effect & $\begin{array}{c}\text { Amara-Mokrane et al. } \\
{[40]}\end{array}$ \\
\hline $10-300 \mathrm{mM} / \mathrm{kg}$ (s.c.) & In Cd-induced liver injury mice & $\begin{array}{l}\text { Increased hepatic MP -I and -II levels. } \\
\text { Exhibited hepatoprotectivity }\end{array}$ & Liu et al. [49] \\
\hline $30 \mathrm{mM} / \mathrm{kg}$ (s.c.) for 3 days & $\begin{array}{c}\text { In acetaminophen-, } \\
\text { bromobenzene-, CCl4-, } \\
\text { furosemide-, thioacetamide-, } \\
\text { CHCl3 and dimethylnitrosamine- } \\
\text { induced liver injury in mice }\end{array}$ & $\begin{array}{l}\text { Exhibited hepatoprotectivity with a } \\
\text { suppression of } \mathrm{P} 450\end{array}$ & Liu et al. [46] \\
\hline $\begin{array}{l}\text { With sapindoside B at } 20 \mathrm{mg} / \mathrm{kg} \\
\text { (s.c.) for } 3 \text { days }\end{array}$ & In mice $(\mathrm{n}=5)$ & $\begin{array}{l}\text { Hepatoprotectivity with a suppressive effect } \\
\text { on liver cytochrome P- } 450\end{array}$ & Shi \& Liu [47] \\
\hline- & In mice & $\begin{array}{l}\text { Significantly decreased the hepatic } \\
\text { content of P450 and the activities of } \\
\text { microsomal ethoxyresorufin O-deethylase, } \\
\text { methoxyresorufin O-demethylase, and } \\
\text { aniline hydroxylase, representative activities } \\
\text { of CYP-4501A1, - } 4501 \mathrm{~A} 2 \text {, and -4502E1 other } \\
\text { than P4502B }\end{array}$ & Jeong [48] \\
\hline- & On CCl4-induced hepatotoxic mice & $\begin{array}{l}\text { Significantly prevented the increase in } \\
\text { serum ALT, LDH and LP activities in a dose } \\
\text { dependent manner }\end{array}$ & Jeong \& Park [50] \\
\hline
\end{tabular}




\begin{tabular}{|c|c|c|c|}
\hline $0.1-20 \mu \mathrm{M}$ & $\begin{array}{c}\text { In mouse hepatoma (Hepa-1c1c7) } \\
\text { cell line }\end{array}$ & $\begin{array}{c}\text { Suppressed TCDD-induced Cyp1a-1 gene } \\
\text { expression with an antagonistic effect of } \\
\text { the DNA binding potential of a nuclear Ah } \\
\text { receptor }\end{array}$ & Jeong \& Lee [51] \\
\hline 3 to $300 \mathrm{mM} / \mathrm{kg}$ (s.c.) & In rats & $\begin{array}{c}\text { Zn depilation with a decreased fetal weight } \\
\text { and increased the incidence of abnormal } \\
\text { fetuses at high dose }\end{array}$ & Daston et al. [56] \\
\hline 20 or $30 \mathrm{mM} / \mathrm{kg}$ for 10 days & In rats & Exhibited a secondary zinc deficiency & Duffy et al. [57] \\
\hline $100 \mu \mathrm{M}$ & $\begin{array}{c}\text { On male Wistar rat isolated } \\
\text { stomach corpus and fundus strips }\end{array}$ & $\begin{array}{c}\text { Ca }{ }^{2+} \text { influx occurred via voltage-dependent } \\
\text { calcium channels of L-type }\end{array}$ & Mendel et al. [58] \\
\hline
\end{tabular}

\section{Conclusion}

Revision accounts $\alpha$-HN to have antioxidant, anti-inflammatory, antiarthritic and bronchiolytic effects. Along with antifungal and antiparasitic activities $\alpha-\mathrm{HN}$ is also a potent cytotoxic agent. Antitumor activity is also demonstrated against a number of cancer cell lines. In addition, $\alpha-\mathrm{HN}$ has desmutagenic hepatoprotective potential.

\section{Featuring}

The methyl ester of $\alpha-\mathrm{HN}$ (60mg/kg, p.o.) is evident to produce strong anti-arthritic activity in carrageenan-induced edema rats and mice [2]. Otherwise, with cisplatin (CP) and thymoquinone (TQ), $\alpha-\mathrm{HN}$ at 6-14 $\mu \mathrm{M}$ exhibited neither cytotoxicity nor apoptosis on the human A549 (lung carcinoma), Hep-2 (larynx epidermoid carcinoma), HT-29 (colon adenocarcinoma) and MIA PaCa-2 (pancreas carcinoma) cell lines [32]. Although, physiological $\mathrm{Zn}^{2+}$ depletion and $\mathrm{Ca}^{2+}$ influx in experimental animals are reported, but synergistic effects with other chemicals as well as antagonistic effects of number of toxicants making $\alpha-\mathrm{HN}$ as an interesting chemical in the advances in pharmacological studies.

\section{Acknowledgement}

I am owed to the NTF, Federal University of Piaui, Brazil for providing internet facility to carry out this revision.

\section{Conflict of Interest}

I have no conflict of interest.

\section{References}

1. Posselt L (1849) On the constituents of the seeds of ivy. J Practical Chem 7: 92-95.

2. Li DW, Hyun JE, Jeong CS, Kim YS, Lee EB (2003) Anti inflammatory activity of alpha-hederin methyl ester from the alkaline hydrolysate of the butanol fraction of Kalopanax pictus bark extract. Biol Pharm Bull 26(4): 429-433.

3. Cheng L, Xia TS, Wang YF, Zhou W, Liang XQ et al. (2014) The anticancer effect and mechanism of $\boldsymbol{\alpha}$-hederin on breast cancer cells. Int J Oncol 45(2): 757-763

4. Liu YP, Liu J (1997) Effect of alpha-hederin on hepatic detoxifying systems in mice. Zhongguo Yao Li Xue Bao 18(1): 33-36.

5. Gülçin I, Mshvildadze V, Gepdiremen A, Elias R (2004) Antioxidant activity of saponins isolated from ivy: alpha-hederin, hederasaponin- $\mathrm{C}$ hederacolchiside-E and hederacolchiside-F. Planta Med 70(6): 561563
6. Pompella A, Visvikis A, Paolicchi A, Tata V, Casini AF (2003) The changing faces of glutathione, a cellular protagonist. Biochem Pharmacol 66(8): 1499-1503.

7. Felizola SJ, Nakamura Y, Arata Y, Ise K, Satoh F, et al. (2014) Metallothionein-3 (MT-3) in the human adrenal cortex and its disorders. Endocr Pathol 25(3): 229-235.

8. Keyhanmanesh R, Saadat S, Mohammadi M, Shahbazfar AA, Fallahi M (2015) The Protective Effect of $\boldsymbol{\alpha}$-Hederin, the Active Constituent of Nigella sativa, on Lung Inflammation and Blood Cytokines in Ovalbumin Sensitized Guinea Pigs. Phytother Res 29(11): 1761-1767.

9. Saadat S, Mohammadi M, Fallahi M, Keyhanmanesh R, Aslani MR (2015) The protective effect of $\boldsymbol{\alpha}$-hederin, the active constituent of Nigella sativa, on tracheal responsiveness and lung inflammation in ovalbumin-sensitized guinea pigs. J Physiol Sci 65(3): 285-292.

10. Ebrahimi H, Fallahi M, Khamaneh AM, Ebrahimi Saadatlou MA, Saadat S, et al. (2016) Effect of $\boldsymbol{\alpha}$-Hederin on IL-2 and IL-17 mRNA and miRNA133a Levels in Lungs of Ovalbumin-Sensitized Male Rats. Drug Dev Res 77(2): 87-93.

11. Wolf A, Gosens R, Meurs H, Häberlein H (2011) Pre-treatment with $\boldsymbol{\alpha}$-hederin increases $\boldsymbol{\beta}$-adrenoceptor mediated relaxation of airway smooth muscle. Phytomedicine 18(2-3): 214-218.

12. Gepdiremen A, Mshvildadze V, Süleyman H, Elias R (2005) Acute anti-inflammatory activity of four saponins isolated from ivy: alphahederin, hederasaponin- $\mathrm{C}$, hederacolchiside- $\mathrm{E}$ and hederacolchiside- $\mathrm{F}$ in carrageenan-induced rat paw edema. Phytomedicine 12(6-7): 440444.

13. Mott HR, Driscoll PC, Boyd J, Cooke RM, Weir MP, et al. (1992) Secondary structure of human interleukin 2 from 3D heteronuclear NMR experiments. Biochem 31(33): 7741-7744.

14. Aggarwal S, Gurney AL (2002) IL-17: prototype member of an emerging cytokine family. J Leukocyte Biol 71(1): 1-8.

15. Schoenborn JR, Wilson CB (2007) Regulation of interferon-gamma during innate and adaptive immune responses. Adv Immunol 96: 41101.

16. Di Giuseppe M (2003) Nelson Biology 12. Toronto: Thomson Canada, pp. 473.

17. Andersen HH, Elberling J, Arendt-Nielsen L (2015) Human surrogate models of histaminergic and non-histaminergic itch. Acta Derm Venereol 95(7): 771-777.

18. Ermert D, Niemiec MJ, Röhm M, Glenthoj A, Borregard N, et al. (2013) Candida albicans escapes mouse neutrophils. J Leukoc Biol 94(2): 223236.

19. Birnbaum S, Barreiro TJ (2007) Methacholine challenge testing: identifying its diagnostic role, testing, coding, and reimbursement. Chest 131(6): 1932-1935

20. Moulin-Traffort J, Favel A, Elias R, Regli P (1998) Study of the action 
of alpha-hederin on the ultrastructure of Candida albicans. Mycoses 41(9-10): 411-416.

21. Delmas F, Di Giorgio C, Elias R, Gasquet M, Azas N, et al. (2000) Antileishmanial activity of three saponins isolated from ivy, alphahederin, beta-hederin and hederacolchiside A1, as compared to their action on mammalian cells cultured in vitro. Planta Med 66(4): 343347.

22. Ridoux O, Di Giorgio C, Delmas F, Elias R, Mshvildadze V, et al. (2001) In vitro antileishmanial activity of three saponins isolated from ivy, alphahederin, beta-hederin and hederacolchiside A(1), in association with pentamidine and amphotericin B. Phytother Res 15(4): 298-301.

23. DEnfert C, Hube B (2007) Candida: Comparative and Functional Genomics. Caister Academic Press, UK, pp. 1-428.

24. Tortora, Gerald J (2010) Microbiology: an Introduction. CA: Pearson Benjamin Cummings, San Francisco, USA, pp. 758.

25. Barrett MP, Croft SL (2012) Management of trypanosomiasis and leishmaniasis. British Med Bull 104: 175-196.

26. World Health Organization (2014) Leishmaniasis Fact sheet $\mathrm{N}^{\circ} 375$. World Health Organization, Geneva, Switzerland.

27. Lorent J, Le Duff CS, Quetin-Leclercq J, Mingeot-Leclercq MP (2013) Induction of highly curved structures in relation to membrane permeabilization and budding by the triterpenoid saponins, $\boldsymbol{\alpha}-$ and $\boldsymbol{\delta}$-Hederin. J Biol Chem 288(20): 14000-14017.

28. Lorent J, Lins L, Domenech ò, Quetin-Leclercq J, Brasseur R, et al (2014) Domain formation and permeabilization induced by the saponin $\boldsymbol{\alpha}$-hederin and its aglycone hederagenin in a cholesterolcontaining bilayer. Langmuir 30(16): 4556-4569.

29. Danloy S, Quetin-Leclercq J, Coucke P, De Pauw-Gillet MC, Elias R, et al. (1994) Effects of alpha-hederin, a saponin extracted from Hedera helix, on cells cultured in vitro. Planta Med 60(1): 45-49.

30. Jeong HG, Choi CY (2002) Expression of inducible nitric oxide synthase by alpha-hederin in macrophages. Planta Med 68(5): 392-396.

31. Swamy SM, Huat BT (2003) Intracellular glutathione depletion and reactive oxygen species generation are important in alpha-hederin induced apoptosis of P388 cells. Mol Cell Biochem 245(1-2): 127-139.

32. Rooney S, Ryan MF (2005) Effects of alpha-hederin and thymoquinone, constituents of Nigella sativa, on human cancer cell lines. Anticancer Res 25(3B): 2199-2204.

33. Kim JY, Choi CY, Jeong HG (2005) Involvement of cytokines in the hepatic metallothionein expression by alpha-hederin. Planta Med 71(8): 743-747.

34. Liu Y, Lu WX, Yan MC, Yu Y, Ikejima T, et al. (2010) Synthesis and tumor cytotoxicity of novel amide derivatives of $\boldsymbol{\beta}$-hederin. Molecules 15(11): 7871-7883.

35. Bang SC, Seo HH, Shin HR, Lee KC, Hoang le TA, et al. (2008) A convenient preparation of a disaccharide motif and its role in the cytotoxicity of the triterpenoid saponin, alpha-hederin. Arch Pharm Res 31(5): 555-561.

36. Bun SS, Elias R, Baghdikian B, Ciccolini J, Ollivier E, et al. (2008) Alpha-hederin potentiates 5-FU antitumor activity in human colon adenocarcinoma cells. Phytother Res 22(10): 1299-1302.

37. Kumara SS, Huat BT (2001) Extraction, isolation and characterisation of antitumor principle, alpha-hederin, from the seeds of Nigella sativa. Planta Med 67(1): 29-32.

38. Sieben A, Prenner L, Sorkalla T, Wolf A, Jakobs D, et al. (2009) Alphahederin, but not hederacoside $\mathrm{C}$ and hederagenin from Hedera helix, affects the binding behavior, dynamics, and regulation of beta 2-adrenergic receptors. Biochem 48(15): 3477-3482.
39.Zhu R, Zhang CG, Liu Y, Yuan ZQ, Chen WL, et al. (2015) CD147 monoclonal antibody mediated by chitosan nanoparticles loaded with $\boldsymbol{\alpha}$-hederin enhances antineoplastic activity and cellular uptake in liver cancer cells. Sci Rep 5: 17904

40. Amara-Mokrane YA, Lehucher-Michel MP, Balansard G, Duménil G, Botta A (1996) Protective effects of alpha-hederin, chlorophyllin and ascorbic acid towards the induction of micronuclei by doxorubicin in cultured human lymphocytes. Mutagenesis 11(2): 161-167.

41. Tian B, Brasier AR (2003) Identification of a nuclear factor kappa B-dependent gene network. Recent Prog Horm Res 58: 95-130.

42. Perkins ND (2007) Integrating cell-signalling pathways with NFkappaB and IKK function. Nat Rev Mol Cell Biol 8(1): 49-62.

43. Devasagayam T, Tilak JC, Boloor KK, Sane Ketaki S, Ghaskadbi Saroj S, et al. (2004) Free Radicals and Antioxidants in Human Health: Current Status and Future Prospects. J Assoc Physicians India 52: 794-804.

44. Lund A, Shimada S, Shiotani M (2011) Principles and Applications of ESR Spectroscopy. Springer, Netherlands, p. 3-28.

45. Ferguson-Smith AC, Chen YF, Newman MS, May LT, Sehgal PB, et al. (1988) Regional localization of the interferon-beta 2/B-cell stimulatory factor 2 /hepatocyte stimulating factor gene to human chromosome 7p15-p21. Genomics 2(3): 203-208.

46. Liu J, Liu Y, Bullock P, Klaassen CD (1995) Suppression of liver cytochrome $\mathrm{P} 450$ by alpha-hederin: relevance to hepatoprotection. Toxicol Appl Pharmacol 134(1): 124-131.

47. Shi JZ, Liu GT (1996) Effect of alpha-hederin and sapindoside B on hepatic microsomal cytochrome P-450 in mice. Zhongguo Yao Li Xue Bao 17(3): 264-266.

48. Jeong HG (1998) Suppression of constitutive and inducible cytochrome P450 gene expression by alpha-hederin in mice. Biochem Mol Biol Int 46(5): 1019-1026.

49. Liu J, Choudhuri S, Liu Y, Kreppel H, Andrews GK, et al. (1993) Induction of metallothionein by alpha-hederin. Toxicol Appl Pharmacol 121(1): 144-151.

50. Jeong HG, Park HY (1998) The prevention of carbon tetrachlorideinduced hepatotoxicity in mice by alpha-hederin: inhibiton of cytochrome P450 2E1 expression. Biochem Mol Biol Int 45(1): 163170.

51. Jeong HG, Lee SS (1999) Suppressive effects of alpha-Hederin on 2,3,7,8-tetrachlorodibenzo-p-dioxin-mediated murine Cyp1a-1 expression in the mouse hepatoma Hepa-1c1c7 cells. Cancer Lett 138(1-2): 131-137.

52. Whitlock JP (1999) Induction of cytochrome P4501A1. Annu Rev Pharmacol Toxicol 39: 103-125.

53. Nelson DR, Zeldin DC, Hoffman SM, Maltais LJ, Wain HM, et al. (2004) Comparison of cytochrome P450 (CYP) genes from the mouse and human genomes, including nomenclature recommendations for genes, pseudogenes and alternative-splice variants. Pharmacogenetics 14(1): $1-18$.

54. Williams FM, Mutch E, Woodhouse KW, Lambert D, Rawlins MD (1986) Ethoxyresorufin 0-deethylation by human liver microsomes. Braz J Clin Pharmacol 22(3): 263-268.

55. Peterson CW, Narula SS, Armitage IM (1996) 3D solution structure of copper and silver-substituted yeast metallothioneins. FEBS Lett 379(1): 85-93.

56. Daston GP, Overmann GJ, Baines D, Taubeneck MW, Lehman-McKeeman LD, et al. (1994) Altered Zn status by alpha-hederin in the pregnant rat and its relationship to adverse developmental outcome. Reprod Toxicol 8(1): 15-24. 
57. Duffy JY, Baines D, Overmann GJ, Keen CL, Daston GP (1997) Repeated administration of alpha-hederin results in alterations in maternal zinc status and adverse developmental outcome in the rat. Teratology 56(5): 327-334

58. Mendel M, Chłopecka M, Dziekan N, Karlik W, Wiechetek M (2013) Participation of extracellular calcium in $\boldsymbol{\alpha}$-hederin-induced contractions of rat isolated stomach strips. J Ethnopharmacol 146(1) 423-426.

59. Plum L, Rink L, Haase H (2010) The Essential Toxin: Impact of Zinc on Human Health. Int J Environ Res Public Health 7(4): 1342-1365.

60. Berdanier CD, Dwyer JT, Feldman EB (2007) Handbook of Nutrition and Food. ( $2^{\text {nd }}$ edn), CRC Press, Boca Raton, Florida, USA, pp. 347.

61. Hambidge KM, Krebs NF (2007) Zinc deficiency: a special challenge. J Nutr 137(4): 1101-1105.

62. Bitanihirwe BK, Cunningham MG (2009) Zinc: The brain's dark horse. Synapse 63(11): 1029-1049.
63. Espino J, Bejarano I, Paredes SD, González D, Barriga C, et al. (2010) Melatonin Counteracts Alterations in Oxidative Metabolism and Cell Viability Induced by Intracellular Calcium Overload in Human Leucocytes: Changes with Age. Basic Clin Pharmacol Toxicol 107(1): 590-597.

64. Ross AC, Taylor CL, Yaktine AL, Del Valle HB (2011) Committee to Review Dietary Reference Intakes for Vitamin D. ISBN: 978-0-30916394-1.

65. Mendel M, Chłopecka M, Dziekan N, Karlik W, Wiechetek M (2012) Participation of cholinergic pathways in $\boldsymbol{\alpha}$-hederin-induced contraction of rat isolated stomach strips. Phytomedicine 19(7): 591-595.

66. Schulte-Michels J, Wolf A, Aatz S, Engelhard K, Sieben A, et al. (2016) $\boldsymbol{\alpha}$-Hederin inhibits G protein-coupled receptor kinase 2-mediated phosphorylation of $\boldsymbol{\beta} 2$-adrenergic receptors. Phytomedicine 23(1): $52-57$

\section{Your next submission with Juniper Publishers} will reach you the below assets

- Quality Editorial service

- Swift Peer Review

- Reprints availability

- E-prints Service

- Manuscript Podcast for convenient understanding

- Global attainment for your research

- Manuscript accessibility in different formats ( Pdf, E-pub, Full Text, Audio)

- Unceasing customer service

Track the below URL for one-step submission https://juniperpublishers.com/online-submission.php 